\section{Commentary: Spinach for Popeye, autogenous mitochondria for us!!}

Federica Caldaroni, $\mathrm{MD},{ }^{\mathrm{a}}$ and
Yves d'Udekem, $\mathrm{MD}, \mathrm{PhD}^{\mathrm{a}, \mathrm{b}, \mathrm{c}}$

In one of the latest movies on Netflix, Project Power, villains and heroes take a pill that reveal the extraordinary super powers that reside in any of us. The concept is not new: vampires drink blood to keep their eternal youth; Popeye eats spinach because of its high content of iron, as the strength of iron symbolizes power. In their latest research, the team of Weixler and colleagues ${ }^{1}$ proposes to inject autogenous mitochondria from skeletal muscles to the free wall of the failing right ventricle (RV) of animal models to increase the mitochondrial function in the RV cardiomyocytes and decrease their apoptosis rate. What is more symbolic for energy than mitochondria, which we have always been taught is the power plant of the cells? But can it work?

There are few data on the remodeling mechanisms of the $\mathrm{RV}$ in response to pressure and volume overload and its subsequent transition to RV failure. Downregulation of the mitochondrial enzymes seems to be a key phenomenon of this process. $^{2}$ Obviously, targeting this maladaptive pathway is an appealing goal. Research in this area is still at its dawn,,$^{3-5}$ and the innovations seem to produce feverish enthusiasm ${ }^{6}$ in a similar way than stem cells research was embraced a few years ago. The authors expanded the already-ongoing research on mitochondrial transplantation, mainly involving the potential treatment of left ventricular failure, ${ }^{4,5,7,8}$ to an animal model of failing $\mathrm{RV}$, obtained by surgical pulmonary artery banding.

From ${ }^{\text {a}}$ Department of Cardiac Surgery, Royal Children's Hospital; ${ }^{b}$ Heart Research, Murdoch Children's Research Institute; and ' Department of Paediatrics, The University of Melbourne, Melbourne, Australia.

Disclosures: Dr d'Udekem is a consultant for MSD and Actelion. He also is a National Health and Medical Research Council Clinician Practitioner Fellow [1082186]. Dr Caldaroni reported no conflicts of interest.

The Journal policy requires editors and reviewers to disclose conflicts of interest and to decline handling or reviewing manuscripts for which they may have a conflict of interest. The editors and reviewers of this article have no conflicts of interest.

Received for publication Oct 7, 2020; revisions received Oct 7, 2020; accepted for publication Oct 8, 2020; available ahead of print Oct 17, 2020.

Address for reprints: Yves d'Udekem, MD, PhD, Children's National Hospital, 111 Michigan Ave, NW, Washington, DC 20010 (E-mail: ydudekem@ childrensnational.org).

J Thorac Cardiovasc Surg 2021;162:e123-4 0022-5223/\$36.00

Copyright (c) 2021 Published by Elsevier Inc. on behalf of The American Association for Thoracic Surgery

https://doi.org/10.1016/j.jtcvs.2020.10.034

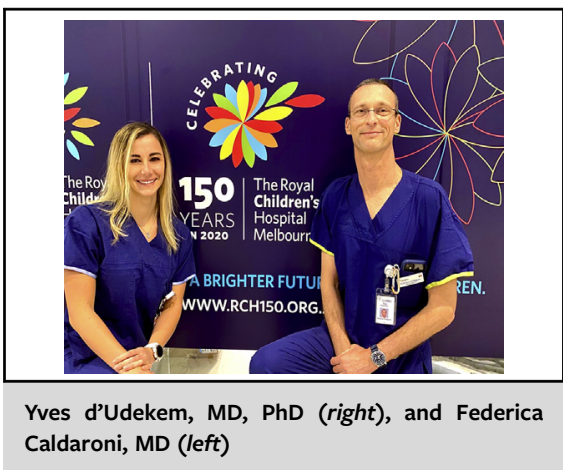

CENTRAL MESSAGE

Autologous mitochondria injection for the treatment of right ventricular failure is appealing; however, more extensive research is needed to identify its real clinical potential.

The RVs of 2 different groups of animal models were injected, respectively, with autologous mitochondria and inactive vehicle. The authors demonstrated that 4 weeks following mitochondrial transplantation, the mitochondriatreated hearts were functionally better than vehicle-treated hearts in terms of contractile function and histologic findings of decreased cardiomyocyte apoptosis, claiming a protective effect induced by the mitochondria injection on the myocardial cells.

Can we be convinced at this stage and are we getting close to the use of this self-described "therapeutic intervention" in clinical practice? First of all, it is likely that this approach would only be useful for a limited subset of patients. Of course, RV pathology is at the core of congenital heart disease in the same way that left ventricular pathology is at the center of acquired adult heart disease. But unlike what is seen in the left ventricle, we only rarely observe failure of the RV that is primarily related to myocardial dysfunction in the setting of hypertrophied RV. ${ }^{9}$ Which failing hypertrophied RVs do we want to help? Patients with old Mustard and Senning? Are they not primarily failing because of arrhythmias ${ }^{10}$ ? Do we not think that many patients with RVs sustaining the systemic circulation are failing because of the unsuitable geometry of the valve annulus that causes these valves to leak? Patients with pulmonary atresia and intact ventricular septum? They are usually failing because of residual obstruction. The patients with single-ventricle 
circulation? Only one-third of them fail because of myocardial dysfunction and only a few because of isolated decreased myocardial strength. ${ }^{11}$ Therefore, there are some doubts that injection of mitochondria would be a universal solution.

But even so, can we believe that injection of mitochondria will work? The present work looks extremely convincing, but those who are not specialists in this topic may have some doubts because of what we witnessed with stem cell therapy research. It has been repeatedly demonstrated that injected stem cells do not stay in the heart for more than a few hours. Why would it be different with mitochondria which are smaller? In addition, one should remember the noise made by the discovery that the injection of dead stem cells and agents promoting inflammation into failing hearts was as efficient as the injection of stem cells. ${ }^{12,13}$

Therefore, the dream of injecting autogenous mitochondria to our defective hearts still remains a sweet dream. It comes from a "high-tech" side of research that has been very promising without yet delivering much of its promises. However, one should be open-minded because often we have seen our wildest dream become reality. People of older generations can look back and imagine what we would have thought if we were said that, one day, we would have in the palm of our hands a phone that would bring at all times information on the entire knowledge of humanity ... and the latest movies from Netflix.

\section{References}

1. Weixler V, Lapusca R, Grangl G, Guariento A, Saeed MY, Cowan DB, et al. Autogenous mitochondria transplantation for treatment of right heart failure. J Thorac Cardiovasc Surg. 2021;162:e111-21.

2. Reddy S, Bernstein D. Molecular mechanisms of right ventricular failure. Circulation. 2015;132:1734-42.

3. Nagendran J, Gurtu V, Fu DZ, Dyck JRB, Haromy A, Ross DB, et al. A dynamic and chamber-specific mitochondrial remodeling in right ventricular hypertrophy can be therapeutically targeted. J Thorac Cardiovasc Surg. 2008; 136:168-78.e3.

4. Emani SM, McCully JD. Mitochondrial transplantation: applications for pediatric patients with congenital heart disease. Transl Pediatr. 2018;7:169-75.

5. Ali Pour P, Kenney MC, Kheradvar A. Bioenergetics consequences of mitochondrial transplantation in cardiomyocytes. J Am Heart Assoc. 2020;9:e014501.

6. Brown DA, Perry JB, Allen ME, Sabbah HN, Stauffer BL, Shaikh SR, et al. Expert consensus document: mitochondrial function as a therapeutic target in heart failure. Nat Rev Cardiol. 2017;14:238-50.

7. Kaza AK, Wamala I, Friehs I, Kuebler JD, Rathod RH, Berra I, et al. Myocardial rescue with autologous mitochondrial transplantation in a porcine model of ischemia/reperfusion. J Thorac Cardiovasc Surg. 2017;153:934-43.

8. Emani SM, Piekarski BL, Harrild D, Del Nido PJ, McCully JD. Autologous mitochondrial transplantation for dysfunction after ischemia-reperfusion injury. $J$ Thorac Cardiovasc Surg. 2017;154:286-9.

9. Vonk Noordegraaf A, Westerhof BE, Westerhof N. The relationship between the right ventricle and its load in pulmonary hypertension. J Am Coll Cardiol. 2017; 69:236-43.

10. Helsen F, Vandenberk B, De Meester P, Van De Bruaene A, Gabriels C, Troost E, et al. Appearance of QRS fragmentation late after Mustard/Senning repair is associated with adverse outcome. Heart Br Card Soc. 2017;103:1036-42.

11. Poh C, Hornung T, Celermajer DS, Radford DJ, Justo RN, Andrews D, et al. Modes of late mortality in patients with a Fontan circulation. Heart Br Card Soc. 2020;106:1427-31.

12. Epstein JA, Rosenthal N, Feldman AM. Teasing the immune system to repair the heart. N Engl J Med. 2020;382:1660-2.

13. Vagnozzi RJ, Maillet M, Sargent MA, Khalil H, Johansen AKZ, Schwanekamp JA, et al. An acute immune response underlies the benefit of cardiac stem cell therapy. Nature. 2020;577:405-9. 